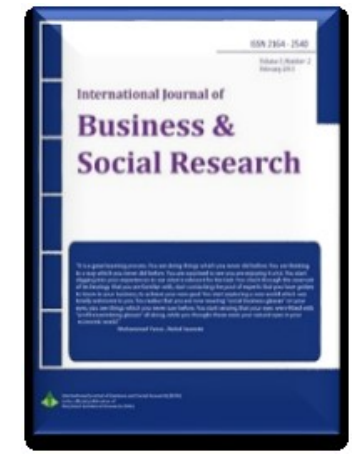

\title{
Study on Total Quality Management Activities in Taiwan Tourism Factories
}

\begin{abstract}
Yi-Chan Chung'
ABSTRACT

As competition becomes increasingly fierce, how to integrate the concept of information technology involvement into total quality management activities and better serve the customers, thus increasing the effectiveness of their services, has become an important focus for many tourism factories in their selection of an appropriate operational strategy. With the tourism factories in Taiwan as the subjects, this study was therefore set out to investigate the impact of operational strategies, information technology involvement and motivation on the executive degree of total quality management (TQM) activities, as well as the correlation between the executive degree of TQM activities and operational performance. This research was conducted from March to April 2016 using 56 effective questionnaires through a questionnaire survey method. According to the research findings, the higher the executive degree of TQM activities was, the more significant a positive impact it would have on operational performance; the execution of differentiation strategies would have a positive impact on the execution of TQM activities; the more a company was involved in information technology, the more significant a positive impact it would have on the execution of TQM activities; the higher the intrinsic motivation was, the more significant a positive impact it would have on the executive degrees of TQM activities. It is therefore advisable for tourism factories to implement TQM activities, adopt differentiation strategies, seek greater information technology involvement and become more strongly motivated toward TQM implementation in order to improve operational performance.
\end{abstract}

Keywords: Information technology, operational performance, operational strategy, total quality management. Available Online: 24-08-2016

This is an open access article under Creative Commons Attribution 4.0 License, 2016.

\section{0}

INTRODUCTION

According to Industrial Development Bureau, Ministry of Economic Affairs, tourism factories are defined as actual manufacturing and processing plants that open their products, production process, premises or sites to the visitors, hence their value in tourism education or industrial culture promotion. As the awareness of the Tourism Factory Assistance Project grows, the number of tourism factories also keeps increasing. Apart from old factories that operate stably along this line, some new factories

\footnotetext{
${ }_{1}$ Department of Business Administration, Yuanpei University of Medical Technology, Taiwan. E-mail: kent4321@ms19.hinet.net
} 
are also transforming themselves toward this direction. Tourism factories in Taiwan have become a new highlight for tourists at home and abroad as a destination for leisure and recreation. However, as people set higher requirements for tourism factories in terms of the quality of their services, this sector is becoming more and more competitive. In order to increase the competitive advantages of tourism factories, it has become especially important for them to improve the quality and effectiveness of their services. Under such circumstances, how to integrate the concept of information technology involvement into total quality management activities and better serve the customers, thus increasing the effectiveness of their services, has become an important focus for many tourism factories in their selection of an appropriate operational strategy. In this study, a questionnaire was formulated after a review of relevant literature. With the tourism factories assisted by the Ministry of Economic Affairs as the samples and subjects of research, it was set out to investigate the correlation among operational strategies, information technology involvement, motivation, TQM and operational performance based on the analysis of the questionnaires.

The objectives of this study included: (1) to probe into the impact of operational strategies on the executive degree of TQM activities; (2) to probe into the impact of information technology involvement on executive degree of TQM activities; (3) to probe into the impact of motivation on executive degree of TQM activities; (4) to probe into the impact of the executive degree of TQM activities on operational performance; (5) to propose the suggestions for tourism factories to implement TQM activities and upgrade operational strategies on the basis of the research findings.

\subsection{LITERATURE REVIEW}

\subsection{OPERATIONAL STRATEGY AND TQM ACTIVITIES}

Croteau and Bergeron (2001) defined operational strategies as the organizations' actions to accomplish the goals. Porter (1980) suggested that in order to acquire or maintain competitive advantages, the firms can adopt cost leadership strategy, differentiation strategy and focus strategy. According to the firms' reactions toward environmental change, Miles \& Snow (1978) divided operational strategies into four types: Prospector Strategy, Defender Strategy, Analyzer Strategy and Reactor Strategy. Song et al (1996) believed that Reactor Strategy is unable to respond to market changes to achieve continuous operation, which, therefore, is a strategy of less competitiveness. Durand \& Coeurderoy (2001) divided operational strategies into (1) cost leadership strategy: to reduce prices of products or services by improving efficiency and reducing costs in order to acquire maximum business volume; (2) marketing differentiation strategy: to provide products and services different from other rivals and value product and service quality, innovation, and originality; and (3) innovation differentiation strategy: to increase competitive advantage by introducing innovative products and services that are not easily imitated by rivals. This study treated cost leadership, marketing differentiation, and innovative differentiation (Durand \& Coeurderoy, 2001) as the defining elements in a tourism factory industry operational strategy.

Jung et al. (2009) suggested that operational strategies are influential on TQM implementation. Prajogo \& Sohall (2006) pointed out that different types of operational strategies adopted by the firms will differently and significantly influence TQM implementation. Prajogo \& Sohal (2001) suggested that differentiation and cost leadership strategies could be used to implement total quality management, and different operational strategies would have a differently significant impact on TQM implementation. Based on the above literature review, this study proposed the following $\mathrm{H}_{1}$ : Different types of operational strategy significantly and differently influence the execution of TQM activities.

\subsection{INFORMATION TECHNOLOGY INVOLVEMENT AND TQM ACTIVITIES}

Roberts (1996) suggested that information technology refers to all software and hardware tools that acquire, apply, display, save, and communicate information. On the basis of a literature review, Li (2006) defined information technology involvement as resources and efforts invested by the 
organization in order to accomplish the management function of information technology. Sakaguchi \& Dibrell (1998) indicated that information technology involvement could be measured by information technology investment and training. Information technology investment is measured by quantitative measures on budgets and software and hardware devices. Information technology training refers to training personnel to use information technology. Miller \& Doyle (1987) suggested that information technology involvement must be based on three aspects: (1) to probe into the importance of information technology in firms; (2) certain investment in software, hardware, and personnel to acquire benefits; (3) personnel training according to the needs of development personnel and users. Based on the literature review (Miller \& Doyle 1987; Sohal et al., 2001; Duffy, 2000; Meso \& Smith, 2000; Sakaguchi \& Dibrell 1998; Li 2006), this study divided information technology involvement into personnel training, investment in hardware and software and the perception of employees.

Siam et al. (2012) and Ang et al. (2000) suggested that information technology involvement is positively related to TQM implementation. Tiwari \& Chaudhari (2012) pointed out that information technology involvement could facilitate TQM implementation, thus achieving organizational performance. Dewhurst et al. (2003) indicated that information technology involvement is conducive to TQM implementation, including in that it could improve the relations with the customers and suppliers, enhance process control, promote teamwork and the flow of information between departments, improve the quality and skills for process design, etc. Based on the above literature review, this study proposed the following $\mathrm{H}_{2}$ : The higher the information technology involvement is, the more significant a positive impact it will have on the execution of TQM activities.

\subsection{MOTIVATION AND TQM ACTIVITIES}

Yusof \& Aspinwall $(2000,2001)$ pointed out that the motivation for a firm to implement TQM is to enhance operational performance and provide high-quality products and services as a response to the customers' needs. In the study of Bhanugopan (2002), the motivation for embarking on TQM was demonstrated to include high-rank managers' awareness of the importance of quality and showing support, employees' spontaneous implementation, customers' needs, threats from competitors, trend of the times and the need to enhance operational performance. Shea \& Gobeli (1995) pointed out that the motivation for embarking on TQM is mainly constructed by high-rank managers' support, a stronger corporate constitution, increase in enterprise competitiveness, stress from the competitors and the need to increase profits. Ghobadian \& Gallear (1996) pointed out that the major motivation for embarking on TQM is to improve corporate constitution. Mcadam \& Mckeown (1999) suggested that the motivation for a firm to embark on TQM is to increase profits, reduce operational costs, address customers' needs, increase production capacities and improve the quality of their products. Mersha (1997) suggested that the motivation for embarking on TQM is comprised of high-rank managers' support, employees' spontaneous implementation, product quality and productivity improvement, response to government policies and knowledge of TQM in terms of their outcomes. Based on the literature review (Levin \& Shortell, 2006; Bhanugopan 2002; Yusof \& Aspinwall, 2001; Mcadam \& Mckeown 1999; Yusof \& Aspinwall, 2000; Mersha 1997; Németh, 1999), this study divided the motivation for embarking on TQM into: (1) intrinsic motivation (the more positive motivation), which is derived from including product or service quality improvement, operational cost reduction, a stronger corporate constitution, greater enterprise competitiveness, high-rank managers' support and employees' spontaneous implementation; (2) extrinsic motivation (the more negative motivation), which is derived from including threats from competitors, trend of times, need to address customers' needs and response to government policies.

As was found in the study of Levin \& Shortell (2006), if a company could hold an active attitude toward the learning and implementation of TQM activities, the result will be a higher executive degree of these activities and better operational performance. Meanwhile, Németh (1999) also suggested that if a company could implement TQM activities at the urge of a more positive motivation, the executive degree of these TQM activities will also go upward. Based on the above literature review, this study proposed the following $\mathrm{H}_{3}$ : Differences in the motivation (intrinsic and extrinsic motivation) for 
embarking on TQM significantly and differently influence the executive degree of TQM activities.

\subsection{TOTAL QUALITY MANAGEMENT (TQM) ACTIVITIES}

According to the definition of Ismail \& Ebrahimpour (2003) of total quality management: "total" represents when all the employees join together with the company as a totality to make continuous improvement; "quality" represents satisfying customers' needs; "management" represents the total commitment and execution of managers. Based on literature review, Seetharaman et al. (2006) generalized 6 key success factors on the execution of TQM activities: high-rank managers' support, employees' active involvement in the implementation, methods to measure the performance, culture of continuous improvement, value on customers' needs, education and employee training. Based on literature review, Motwani (2001) generalized 7 constructs of the execution of TQM activities, including high-rank managers' support, quality measurement and benchmarking, manufacturing management, product design, employee training and empowerment, supplier quality management and customer participation and satisfaction. Based on relevant literature review, Antony et al. (2002) suggested 11 key success factors of the execution of TQM activities, including educational training, quality data and figure analysis, the managers' commitment, customer satisfaction orientation, role of quality control department, communication for quality improvement, continuous improvement, product and service design, the suppliers' quality management, manufacturing management and employee relationship. By keywords searching, Ismail \& Ebrahimpour (2003) organized the key success factors of effective TQM activities execution, including leadership, strategic planning, customer and market orientation, data analysis, human resource management, process management. Based mainly on relevant literature review (Antony et al. 2002; Seetharaman et al. 2006; Motwani 2001; Ismail \& Ebrahimpour 2003) and the suggestions of scholars and experts, this study revised and formulated the factors of TQM activities. Accordingly, TQM activities were divided into five constructs (leadership, data analysis, human resource management, process management and customer and market orientation) and 28 activities.

\subsection{TQM ACTIVITIES AND OPERATIONAL PERFORMANCE}

Kirca et al. (2005) measured performance by the four indicators of overall business performance, profit rate, sales, and market share. Tippins \& Sohi (2003) measured organizational performance by profit rate, return on investment, customer maintenance rate, and growth of sales. Farrell (2000) suggested that business performance referred to the customer maintenance rate, new product success rate, growth of sales, return on investment, and overall performance of one firm compared with others. Chow et al. (2003) measured performance by such indicators as long term profitability, revenue growth and financial capability. Slater \& Naver (2000) evaluated the performance of firms by return on investment. Croteau \& Bergeron (2001) measured the performance of firms by the two constructs of the ability to make profits and sales growth. Taking both relevant literature and the operational characteristics of tourism factories into consideration, this study measured performance by the seven indicators of performance in meeting operational targets, satisfaction with the quality of service, income growth, percentage of repeat visitors, increase in the effectiveness of service, arrivals growth rate, competitiveness of the tourism factory.

Kaynak (2003) indicated that the higher the executive degree of TQM activities is, the better the firm's operational performance will be. Krajewski \& Ritzman (2002) suggested that the implementation of TQM activities could increase inventory turnover ratio, reduce inventory, solve the problems of scheduling and production, encourage the employees to continue improving the process and product quality and enhance operational performance. Douglas \& Judge (2001) proposed that TQM activities constituted a potential source of competitiveness for companies, namely the companies which implemented TQM activities would have more competitive advantages than those without TQM activities. Hendricks \& Singhal (2001) suggested that when the management support and involve in TQM activities, operational performance would be better. Kunst \& Lemmink (2000) argued that the 
implementation of TQM activities will lead to a significant improvement in operational performance (efficiency, cost and quality of service). Agus \& Abdullah (2000) proposed that the execution time of TQM activities would influence operational performance. The longer the execution time is, the better the operational performance. Based on the literature review, this study proposed the following $\mathrm{H}_{4}$ : The higher the executive degree of TQM activities is, the more significant a positive impact it will have on operational performance.

\subsection{SIZE OF TOURISM FACTORIES AND OPERATIONAL PERFORMANCE}

As to enterprise scale, Quek \& Yusof (2003) suggested that large-scale enterprises' implementation level of TQM activities was different from that of small and medium enterprises. Large-scale enterprises had more resources and their implementation level of TQM activities and operational performance were better than those in small and medium enterprises. Moreover, Terziovski \& Samson (2000) demonstrated that compared with small-scale firms, the implementation level of TQM activities in large-scale enterprises was more significant and they were more likely to reduce the defective rate and guarantee cost of the products through the collection and analysis of the questionnaires they distributed to 962 Australian manufacturers and 379 manufacturers in New Zealand in an attempt to probe into the execution of TQM activities in large-scale enterprises and small and medium enterprises. However, Hendricks \& Singhal (2001) demonstrated the opposite results which showed that compared with large-scale companies, small enterprises could effectively implement TQM activities and enhance their operational performance. Based on the literature review, this study proposed the following $\mathrm{H}_{5}$ : Differences in the size of tourism factories and the executive degree of TQM activities significantly and differently influence operational performance.

\subsection{RESEARCH METHOD}

With tourism factories as the subjects of study and questionnaires as the basis of analysis, this study probes into the correlation among operational strategies, information technology involvement, motivation, the executive degree of TQM activities and operational performance. According to the literature review, the hypotheses are developed below:

$H_{1:}$ Different types of operational strategy significantly and differently influence the execution of TQM activities.

$\mathrm{H}_{2}$ : The higher the information technology involvement is, the more significant a positive impact it will have on the execution of TQM activities.

$\mathrm{H}_{3}$ : Differences in the motivation (intrinsic and extrinsic motivation) for embarking on TQM activities significantly and differently influence the executive degree of TQM activities.

$\mathrm{H}_{4}$ : The higher the executive degree of TQM activities is, the more significant a positive impact it will have on operational performance.

$\mathrm{H}_{5}$ : Differences in the size of tourism factories and the executive degree of TQM activities significantly and differently influence TQM implementation.

\subsection{QUESTIONNAIRE COLLECTION AND DATA ANALYSIS}

The questionnaire used in this study consists of six sections. The first section is about: operational strategies, which mainly include (1) cost leadership strategy; (2) marketing differentiation strategy; (3) innovative differentiation strategy. The second section is devoted to: information technology involvement, which mainly include the three constructs of (1) personnel training; (2) investment in software and hardware; and (3) perceptions of employees. The third section is concerned with: motivation for embarking on TQM, which mainly include (1) intrinsic motivation; and (2) extrinsic motivation. The fourth section is on: the executive degree of TQM activities, which include mainly the five constructs of (1) leadership; (2) data analysis; (3) human resource management; (4) process management; and (5) customer and market orientation. The fifth section elaborates on: operational performance, which includes such seven indicators as performance in meeting operational targets, 
satisfaction with the quality of service, income growth, percentage of repeat visitors, increase in the effectiveness of service, arrivals growth rate, competitiveness of the tourism factory. The sixth section accounts for the size of tourism factories: according to the level of capital and number of employees, the size of tourism factories is divided into large, medium, and small. Research samples were 135 tourism factories evaluated and guided by the Industrial Development Bureau, Ministry of Economic Affairs and data were collected using questionnaires. The respondents were supervisors in charge of tourism factory operations. From March to April 2016 this study obtained 56 valid questionnaires by questionnaire survey.

\begin{tabular}{llr}
\hline \multicolumn{2}{c}{ Table 1: The Cronbach's coefficients for all variables in this study } \\
\hline Questionnaire Dimension & Cronbach's a \\
\hline \multirow{3}{*}{ Operational strategy } & Cost leadership & 0.823 \\
& Marketing differentiation & 0.764 \\
& Innovative differentiation & 0.792 \\
Information & Personnel training & 0.873 \\
involvement & Investment in software and hardware & 0.859 \\
& Perception of employees & 0.894 \\
Total quality management & 0.836 \\
& Leadership & 0.879 \\
& Data analysis & 0.899 \\
Business performance & Human resources management & 0.908 \\
& Process management & 0.857 \\
& Customer and market orientation & 0.892
\end{tabular}

Table 1 shows the reliability values. Nunnally (1978) suggested that in an exploratory study, a reliability greater than 0.7 is acceptable. All the reliability variables of this study are above 0.7 , so the results carry sufficient reliability. This study analyzes data by SPSS. The data analysis method was analysis of variance (ANOVA).

\subsection{MEASUREMENT OF VARIABLES}

The variables include type of operational strategy, information technology involvement, motivation for embarking on TQM, the executive degree of TQM activities, operational performance and size of the tourism factories. The measurement of the variables is shown below:

\subsubsection{MEASUREMENT OF OPERATIONAL STRATEGIES}

Referring to the empirical questionnaires developed by Durand \& Coeurderoy (2001), Prajogo \& Sohal (2006) and the business characteristics of tourism factories, this study categorizes operational strategies as follows:

1. Cost leadership strategy, which includes: (a) investment by tourism factories in techniques or equipment that can save costs; (b) limit cost of production or services to lower levels in tourism factories; (c) reduce cost by improving business and services; (d) make efforts to decrease costs in order to provide products and services with prices lower than those of rivals.

2. Marketing differentiation strategy, which includes: (a) efforts made by tourism factories to offer products and services with more value than those of rivals; (b) according to customers' different needs, tourism factories will provide proper products and services; (c) efforts to provide products and services of a higher quality and better characteristics than those of rivals.

3. Innovative differentiation strategy, which includes: (a) making it difficult for rivals to imitate the tourism factory's products and services; (b) providing better products and services than rivals by re-designing the content of tourism services; (c) providing better products and services than rivals through new techniques or approaches. 
The measurement is based on a Likert 5-point scale, ranging from 5 (strongly agree) to 1 (strongly disagree).

\subsubsection{MEASUREMENT OF INFORMATION TECHNOLOGY INVOLVEMENT}

Based on a literature review (Miller \& Doyle 1987; Sohal et al., 2001; Sakaguchi \& Dibrell 1998; Li 2006) on the constructs of information technology involvement, this study divided information technology involvement into three dimensions: personnel training, investment in software and hardware and perception of employees.

1. Personnel training: It includes that employees receive sufficient training in information technology; employees are familiar with the use of information technology; organizations have adequate professional information technology personnel; organizations have complete teaching materials and manuals for the information system.

2. Investment in software and hardware: It includes that organizations have sufficient funds in information technology; organizations invest in sufficient information technology software; organizations invest in sufficient information technology hardware.

3. Perception of employees: It includes the organization's support for information technology involvement; employees' recognition of the importance of information technology; employees' high acceptance of information technology.

The measurement is based on a Likert 5-point scale, ranging from 5 (strongly agree) to 1 (strongly disagree).

\subsubsection{MEASUREMENT OF MOTIVATION}

Based on a review of relevant literature, this study divided motivation into:

1. Intrinsic motivation: the sources of which include product or service quality improvement, operational cost reduction, a stronger corporate constitution, greater enterprise competitiveness, high-rank managers' support and employees' spontaneous implementation.

2. Extrinsic motivation: the sources of which include threats from competitors, trend of times, need to address customers' needs and response to government policies.

The respondents of the questionnaire were the managers held responsible for the operations of the tourism factories and a nominal scale was used to measure the degree of intrinsic and extrinsic motivation. The sources of intrinsic motivation were divided into the six categories of product or service quality improvement, operational cost reduction, a stronger corporate constitution, greater enterprise competitiveness, high-rank managers' support and employees' spontaneous implementation. 1 refers to one checked category, 6 refers to six checked categories and o refers to no category checked. The sources of Extrinsic motivation were divided into the four categories of threats from competitors, trend of the times, the need to address customers' needs and response to government policies. 1 refers to one checked category, 4 refers to four checked categories and o refers to no category checked.

\subsubsection{MEASUREMENT OF THE EXECUTIVE DEGREE OF TQM ACTIVITIES}

Based mainly on a review of relevant literature and the business characteristics of tourism factories, this study revised and formulated the items of TQM activities. Accordingly, TQM activities in tourism factories were divided into five constructs and 28 activities, which refer respectively to:

1. Leadership: The activities include: (a) the managers would regularly guide the members and examine the business and service quality; (b) the managers show determination of TQM implementation to all the employees; (c) the managers treat quality as the priority in decision-making; (d) distributing resources and improving the quality; (e) carefully establishing the goals of business and service quality; and ( $f$ ) encouraging the employees to participate in quality management.

2. Data analysis: The activities include: (a) the tourism factories would collect, reorganize and 
analyze quality related data; (b) treating the major rivals' advantages as the model; (c) finding the key quality index for analysis; (d) constructing effective quality data and performance measurement; (e) ensuring the completeness of data saving and transmission.

3. Human resources management: The activities include: (a) tourism factories would conduct educational training for the employees and regularly evaluate the results; (b) encouraging the employees' innovation and continuous improvement; (c) rewarding the employees who were devoted to fulfill the quality goals; (d) distributing the necessary resources to the employees and solving their problems; (e) encouraging the employees to propose suggestions on quality improvement for reviewing and further execution; and (f) establishing the incentive system which met the employees' needs.

4. Process management: The activities include: (a) the tourism factories would monitor the business and service process with statistical methods; (b) continuously improving the business and service process to enhance quality; (c) improving the business and process through quality control; (d) designing business and service process by quality factors; (e) regularly reviewing and properly modifying the process indices; and (f) continuously examining and measuring the process performance.

5. Customer and market orientation: The activities include: (a) the tourism factories would actively study the customers' complaints; (b) probing into the customers' satisfaction with the products or services by systematic surveys; (c) collecting the customers' responses to control their needs; (d) immediately responding to the customers' comments and (e) actively finding the approaches to increase customer satisfaction.

The measurement is based on a Likert 5-point scale, ranging from 5 (strongly agree) to 1 (strongly disagree).

\subsubsection{MEASUREMENT OF OPERATIONAL PERFORMANCE}

According to the review of relevant literature and the business characteristics of tourism factories, this study uses performance in meeting operational targets, satisfaction with the quality of service, income growth, percentage of repeat visitors, increase in the effectiveness of service, arrivals growth rate, competitiveness of the tourism factory as measures of performance. The measurement is based on a Likert 5-point scale, ranging from 5 (strongly agree) to 1 (strongly disagree).

\subsubsection{MEASUREMENT OF THE SIZE OF TOURISM FACTORIES}

This study classified tourism factories into those that are large (over 200 employees), medium (between 20 to 200 employees) and small (fewer than 20 employees).

\subsection{RESEARCH RESULTS}

\subsection{OPERATIONAL STRATEGIES AND THE EXECUTIVE DEGREE OF TQM ACTIVITIES}

This study divided operational strategies (cost leadership, marketing differentiation, and innovative differentiation) into two groups (high and low implementation levels). According to the average score of the executive degree of TQM activities (leadership, data analysis, human resources management, process management and customer and market orientation) in the two groups, the researcher tried to find whether there is any significant variance between them. Analysis of the variance in the influence of operational strategy on the executive degree of TQM activities is shown in Table 2. The result supports H1: Different types of operational strategy significantly and differently influence the execution of TQM activities. The execution of differentiation strategies facilitates the execution of TQM activities. But the executive degree of cost leadership strategy does not significantly influence the executive degree of TQM activities. 


\begin{tabular}{|c|c|c|c|c|}
\hline & & Cost leadership & $\begin{array}{r}\text { Marketing } \\
\text { differentiation }\end{array}$ & $\begin{array}{r}\text { Innovative } \\
\text { differentiation }\end{array}$ \\
\hline \multirow{4}{*}{ Leadership } & Low $^{\#}$ & 4.078 & 3.694 & 3.729 \\
\hline & $\mathrm{High}^{\#}$ & 4.289 & 4.257 & 4.283 \\
\hline & F-value & 1.841 & 7.263 & 9.212 \\
\hline & P-value & 0.183 & $0.010^{*}$ & $0.004 *$ \\
\hline \multirow{4}{*}{ Data analysis } & Low $^{\#}$ & 4.036 & 3.633 & 3.725 \\
\hline & $\mathrm{High}^{\#}$ & 4.179 & 4.183 & 4.194 \\
\hline & F-value & 0.650 & 5.433 & 4.916 \\
\hline & P-value & 0.425 & $0.025^{*}$ & $0.033 *$ \\
\hline \multirow{4}{*}{$\begin{array}{l}\text { Human resources } \\
\text { management }\end{array}$} & Low $^{\#}$ & 4.023 & 3.333 & 3.521 \\
\hline & High $^{\#}$ & 4.149 & 4.219 & 4.217 \\
\hline & F-value & 0.395 & 12.471 & 9.290 \\
\hline & P-value & 0.533 & $0.001 *$ & $0.004^{*}$ \\
\hline \multirow{4}{*}{$\begin{array}{l}\text { Process } \\
\text { management }\end{array}$} & Low $^{\#}$ & 3.871 & 3.467 & 3.604 \\
\hline & $\mathrm{High}^{\#}$ & 4.149 & 4.074 & 4.096 \\
\hline & F-value & 2.837 & 6.323 & 6.041 \\
\hline & P-value & 0.100 & $0.016^{*}$ & $0.019 *$ \\
\hline \multirow{4}{*}{$\begin{array}{l}\text { Customer and } \\
\text { market orientation }\end{array}$} & Low $^{\#}$ & 4.264 & 3.667 & 3.900 \\
\hline & High $^{\#}$ & 4.295 & 4.383 & 4.368 \\
\hline & F-value & 0.032 & 10.759 & 5.163 \\
\hline & P-value & 0.860 & $0.002 *$ & $0.029 *$ \\
\hline Note: & $\begin{array}{l}\text { score in } \\
\text { score in }\end{array}$ & $\begin{array}{l}\text { n strategies is lo } \\
\text { onal strategies is }\end{array}$ & $\begin{array}{l}\text { han } 3.5 ; \\
\text { er than } 3.5 ; * p\end{array}$ & \\
\hline
\end{tabular}

\subsection{INFORMATION TECHNOLOGY INVOLVEMENT AND THE EXECUTIVE DEGREE OF TQM ACTIVITIES}

This section probes into the influence of information technology involvement on the executive degree of TQM activities. It divides information technology involvement (perception of employees, investment in hardware and software, personnel training) into two groups (high and low).

According to the average score of the executive degree of the activities in the two groups, the researcher tries to find whether there is any significant variance between them. Analysis of the variance in the influence of information technology involvement on the executive degree of TQM activities is shown in Table 3. The result supports $\mathrm{H}_{2}$ : The degree of information technology involvement significantly and positively influences the executive degree of TQM activities.

\subsection{MOTIVATION AND THE EXECUTIVE DEGREE OF TQM ACTIVITIES}

This section probes into the influence of motivation on the executive degree of TQM activities. It divides intrinsic and extrinsic motivation into two groups (high and low). According to the average score of the executive degree of the activities in the two groups, the researcher tries to find whether there is any significant variance between them. Analysis of the variance in the influence of motivation on the executive degree of TQM activities is shown in Table 4. The result supports $\mathrm{H}_{3}$ : Differences in the motivation (intrinsic and extrinsic motivation) to execute the activities significantly and differently influence the executive degree of TQM activities. The higher the intrinsic motivation (the more positive motivation) is, the more significantly and positively it will influence the executive degree of TQM activities. The degree of extrinsic motivation, however, will not influence significantly the executive degree of TQM activities. 


\begin{tabular}{|c|c|c|c|c|}
\hline \multicolumn{5}{|c|}{ Table 3: ANOVA of information technology involvement on TQM activities } \\
\hline & & $\begin{array}{r}\text { Personnel } \\
\text { training }\end{array}$ & $\begin{array}{r}\text { Investment in software } \\
\text { and hardware }\end{array}$ & $\begin{array}{r}\text { Perception of } \\
\text { employees }\end{array}$ \\
\hline \multirow{4}{*}{ Leadership } & Low $^{\#}$ & 3.975 & 4.032 & 3.861 \\
\hline & High $^{\#}$ & 4.365 & 4.422 & 4.304 \\
\hline & F-value & 6.930 & 6.358 & 7.517 \\
\hline & P-value & $0.012 *$ & $0.016 *$ & $0.009 *$ \\
\hline \multirow{4}{*}{ Data analysis } & Low $^{*}$ & 3.850 & 3.923 & 3.817 \\
\hline & High $^{\#}$ & 4.343 & 4.413 & 4.221 \\
\hline & F-value & 9.550 & 8.604 & 4.797 \\
\hline & P-value & $0.004 *$ & $0.006 *$ & $0.035 *$ \\
\hline \multirow{4}{*}{$\begin{array}{l}\text { Human resources } \\
\text { management }\end{array}$} & Low $^{\#}$ & 3.808 & 3.897 & 3.597 \\
\hline & High $^{\#}$ & 4.341 & 4.400 & 4.281 \\
\hline & F-value & 8.519 & 6.778 & 12.653 \\
\hline & P-value & $0.006^{*}$ & $0.013 *$ & $0.001 *$ \\
\hline \multirow{4}{*}{$\begin{array}{l}\text { Process } \\
\text { management }\end{array}$} & Low $^{\#}$ & 3.725 & 3.795 & 3.667 \\
\hline & High" $^{\#}$ & 4.262 & 4.356 & 4.138 \\
\hline & F-value & 13.301 & 13.528 & 7.559 \\
\hline & P-value & $0.001 *$ & $0.001 *$ & $0.009 *$ \\
\hline \multirow{4}{*}{$\begin{array}{l}\text { Customer and } \\
\text { market orientation }\end{array}$} & Low $^{\#}$ & 4.080 & 4.107 & 3.967 \\
\hline & High$^{\#}$ & 4.467 & 4.573 & 4.407 \\
\hline & F-value & 5.625 & 7.974 & 6.107 \\
\hline & P-value & $0.023^{*}$ & $0.007^{*}$ & $0.018 *$ \\
\hline
\end{tabular}

Note: Low ${ }^{\#}$ : Degree of information technology involvement is lower than 3.5;

High*: Degree of information technology involvement is higher than $3.5 ;{ }^{*} \mathrm{p}<0.05$.

\begin{tabular}{|c|c|c|c|c|c|}
\hline \multicolumn{6}{|c|}{ Table 4: ANOVA of motivation on TQM activities } \\
\hline \multicolumn{4}{|c|}{ Intrinsic motivation } & \multicolumn{2}{|c|}{ Extrinsic motivation } \\
\hline \multirow{4}{*}{ Leadership } & Low $^{\#}$ & 3.955 & \multirow{4}{*}{ Leadership } & Low & 4.100 \\
\hline & $\mathrm{High}^{\#}$ & 4.465 & & High $^{\wedge}$ & 4.204 \\
\hline & F-value & 15.830 & & F-value & 0.201 \\
\hline & P-value & $<0.001 *$ & & P-value & 0.656 \\
\hline \multirow{4}{*}{ Data analysis } & Low $^{\#}$ & 3.909 & \multirow{4}{*}{ Data analysis } & Low $^{\wedge \#}$ & 3.720 \\
\hline & High $^{\#}$ & 4.326 & & $\mathrm{High}^{\wedge}$ & 4.156 \\
\hline & F-value & 6.365 & & F-value & 2.749 \\
\hline & P-value & $0.016 *$ & & P-value & 0.105 \\
\hline \multirow{4}{*}{$\begin{array}{l}\text { Human } \\
\text { resources } \\
\text { management }\end{array}$} & Low $^{\#}$ & 3.826 & \multirow{4}{*}{$\begin{array}{l}\text { Human } \\
\text { resources } \\
\text { management }\end{array}$} & Low^ & 4.102 \\
\hline & $\mathrm{High}^{\#}$ & 4.379 & & High^ $^{\wedge}$ & 3.933 \\
\hline & F-value & 9.209 & & F-value & 0.302 \\
\hline & P-value & $0.004^{*}$ & & P-value & 0.586 \\
\hline \multirow{4}{*}{$\begin{array}{l}\text { Process } \\
\text { management }\end{array}$} & Low $^{\#}$ & 3.818 & \multirow{4}{*}{$\begin{array}{l}\text { Process } \\
\text { management }\end{array}$} & Low^ & 4.037 \\
\hline & High $^{\#}$ & 4.211 & & $\mathrm{High}^{\wedge}$ & 3.733 \\
\hline & F-value & 6.095 & & F-value & 1.409 \\
\hline & P-value & $0.018^{*}$ & & P-value & 0.242 \\
\hline \multirow{4}{*}{$\begin{array}{l}\text { Customer and } \\
\text { market } \\
\text { orientation }\end{array}$} & Low $^{\#}$ & 4.090 & \multirow{4}{*}{$\begin{array}{l}\text { Customer and } \\
\text { market } \\
\text { orientation }\end{array}$} & Low^ & 4.301 \\
\hline & High $^{\#}$ & 4.278 & & High $^{\wedge}$ & 4.120 \\
\hline & F-value & 6.183 & & F-value & 0.462 \\
\hline & P-value & $0.017^{*}$ & & P-value & 0.501 \\
\hline \multicolumn{3}{|c|}{$\begin{array}{l}\text { Low }^{\#} \text { : The number of entries for positive } \\
\text { motivation is smaller than } 3 \text {; High\# }{ }^{\#} \text { The number of } \\
\text { entries for positive motivation is greater than } 3 ; \text { * } \\
p<0.05 \text {. }\end{array}$} & \multicolumn{3}{|c|}{$\begin{array}{l}\text { Low }^{*} \text { : The number of entries for negative } \\
\text { motivation is greater than 2; High }{ }^{\#} \text { : The } \\
\text { number of entries for negative motivation is } \\
\text { smaller than } 2 ;{ }^{*} \mathrm{p}<0.05 \text {. }\end{array}$} \\
\hline
\end{tabular}




\subsection{EXECUTIVE DEGREE OF TQM ACTIVITIES AND OPERATIONAL PERFORMANCE}

This study divided the executive degree of TQM activities (leadership, data analysis, human resources management, process management, and customer and market orientation) into two groups (high and low implementation levels). According to the average score of the activities in the two groups, the researcher tries to find whether there is any significant variance between them. Analysis of the variance in the influence of the executive degree of TQM activities on operational performance is shown in Table 5. The result supports $\mathrm{H}_{4}$.

Table 5: ANOVA of TQM activities on operational performance.

\begin{tabular}{|c|c|c|}
\hline & & ormance \\
\hline \multirow{4}{*}{ Leadership } & Low $^{\#}$ & 3.143 \\
\hline & High $^{\#}$ & 3.984 \\
\hline & F-value & 10.175 \\
\hline & P-value & $0.003^{*}$ \\
\hline \multirow{4}{*}{ Data analysis } & Low $^{\#}$ & 3.214 \\
\hline & $\mathrm{High}^{\#}$ & 4.043 \\
\hline & F-value & 16.308 \\
\hline & P-value & $<0.001^{*}$ \\
\hline \multirow{4}{*}{ Human resources management } & Low $^{\#}$ & 3.329 \\
\hline & High $^{\#}$ & 4.060 \\
\hline & F-value & $14 \cdot 364$ \\
\hline & P-value & $0.001 *$ \\
\hline \multirow{4}{*}{ Process management } & Low $^{\#}$ & 3.238 \\
\hline & High $^{\#}$ & 3.992 \\
\hline & F-value & $9 \cdot 366$ \\
\hline & P-value & $0.004^{*}$ \\
\hline \multirow{4}{*}{ Customer and market orientation } & Low $^{\#}$ & 3.286 \\
\hline & High $^{\#}$ & 4.026 \\
\hline & F-value & 11.989 \\
\hline & P-value & $0.001 *$ \\
\hline
\end{tabular}

\subsection{THE INFLUENCE OF THE EXECUTIVE DEGREE OF TQM ACTIVITIES ON THE TOURISM FACTORIES WITH DIFFERENT SCALE ON BUSINESS PERFORMANCE}

This section explores the influence of executive degree of TQM activities of the tourism factories with different scale on business performance.

Table 6: ANOVA of scale on TQM activities

\begin{tabular}{lrr}
\hline & & Scale \\
\cline { 2 - 3 } & F-value & P-value \\
\hline Leadership & 0.426 & 0.656 \\
Data analysis & 1.693 & 0.198 \\
Human resources management & 0.782 & 0.465 \\
Process management & 0.752 & 0.478 \\
Customer and market orientation & 1.482 & 0.240 \\
\hline
\end{tabular}

The results in Table 6 show that scale do not have a significant influence on the executive degree of TQM activities. Table 7 reveals that the tourism factories from different scale do not reveal a significant influence on their business performance. As seen above, for the tourism factories with different scale, the executive degree of TQM activities do not reveal significant impact on business performance. The 
research results thus reject $\mathrm{H}_{5}$ : Differences in the size of tourism factories and the executive degree of TQM activities significantly and differently influence TQM implementation. Instead, it is shown by the study that differences in the size of tourism factories do not significantly and differently influence the executive degree of TQM activities or the operational performance of a firm.

\begin{tabular}{lrr}
\hline \multicolumn{2}{c}{ Table 7: ANOVA of scale on operational performance } & \\
\cline { 2 - 3 } & & Scale \\
\hline Operational performance & F-value & P-value \\
\hline
\end{tabular}

\subsection{CONCLUSION}

As competition becomes increasingly fierce, how to integrate the concept of information technology involvement into total quality management activities and better serve the customers, thus increasing their operational performance, has become an important focus for many tourism factories in their selection of an appropriate operational strategy. With the tourism factories in Taiwan as the subjects, this study was therefore set out to investigate the impact of operational strategies, information technology involvement and motivation on correlation between the executive degree of total quality management (TQM) activities, as well as the correlation between the executive degree of TQM activities and operational performance. According to the research findings, the higher the executive degree of TQM activities was, the more significant a positive impact it would have on operational performance; the execution of differentiated strategies would have a positive impact on the execution of TQM activities; the more a company was involved in information technology, the more significant a positive relevant it would have on the execution of TQM activities; the higher the intrinsic motivation was, the more significant a positive impact it would have on the executive degrees of TQM activities. It is therefore advisable for tourism factories to implement TQM activities, adopt differentiated strategies, seek greater information technology involvement and become more strongly motivated toward TQM implementation in order to improve operational performance.

\section{ACKNOWLEDGEMENT}

The authors thank the Ministry of Science and Technology of Taiwan for financially supporting this research under Project No. MOST 104-2221-E-264-002

\section{REFERENCES}

Agus, A., \& Abdullah, M. (2000). Total quality management practices in manufacturing companies in Malaysia: an exploratory analysis. Total Quality Management, 11(8), 1041-1052.

Ang, C.L., Davies, M., \& Finlay, P.N. (2000). Measures to assess the impact of information technology on quality management. International Journal of Quality \& Reliability Management, 17 (1), 42 - 66.

Antony, J., Leung, K., Knowles, G., \& Gosh, S. (2002). Critical success factors of TQM implementation in Hong Kong industrials. International Journal of Quality \& Reliability Management, 19(5), 551-566.

Bhanugopan, R. (2002). Total quality management in Papua New Guinea: a survey of current practices. The TQM Magazine, 14(2), 120-126.

Chow, C.W., Haddad, K.M., \& Wu, A. (2003). Corporate Culture and Its Relation to Performance: A Comparative Study of Taiwanese and U.S. Manufacturing Firms. Managerial Finance, 29(12), 65-76.

Croteau, A.M. and Bergeron, F. (2001). An information technology trilogy: business strategy, technological deployment and organizational performance. Journal of Strategic Information Systems, 10(2), 77-99.

Dewhurst, F.W., Martínez-Lorente A.R., \& Sánchez-Rodríguez, C. (2003). An initial assessment of the influence of IT on TQM: a multiple case study. International Journal of Operations and Production Management, 23 (4), 348-374.

Douglas, T.J., \& Judge, W.Q. (2001). Total quality management implementation and competitive advantage: The role of structural control and exploration. Academy of Management Journal, 44(1), 
158-169.

Duffy, J. (2000). The KM technology infrastructure. Information Management Journal, 34(2), 62-66.

Durand, R. and Coeurderoy, R. (2001). Age, order of entry, strategic orientation, and organizational performance. Journal of Business Venturing, 16 (5), 471-494.

Farrell, M.A. (2000). Developing A Market-Oriented Learning Organization. Australian Journal of Management, 25(2), 201-223.

Ghobadian, A., \& Gallear, D. (1996). Total quality management in SMEs, Omega, 24(1), 83-93.

Hendricks, K.B., \& Singhal V.R. (2001). Firm characteristics, total quality management, and financial performance. Journal of Operations Management, 19(3), 269-285.

Ismail, S., \& Ebrahimpour, M. (2003). Examination and Comparison of the Critical Factors of Total Quality. Management (TQM) Across Countries. International Journal of Production Research, 41(2), 235-268.

Jung, J.Y., Wang, Y.J., \& Wu, S. (2009). Competitive strategy, TQM practice, and continuous improvement of international project management: A contingency study. International Journal of Quality \& Reliability Management, 26 (2), 164 - 183

Kaynak, K. (2003). The relationship between total quality management practices and their effects of firm performance. Journal of Operations Management, 21(4), 405-435.

Kirca, A.H., Jayachandran, S., \& Bearden, W.O. (2005). Market orientation: A meta-analytic review and assessment of its antecedents and impact on performance. Journal of Marketing, 69 (2), 24-41.

Kunst, P., \& Lemmink, J., 2000. Quality management and business performance in hospitals: A search for success parameters. Total Quality Management, 11(8), 1123-1133.

Krajewski, L.J., \& Ritzman, L.P., 2002. Operations Management: Strategy and Analysis. 6th Ed., Englewood Cliffs, NJ: Prentice Hall.

Levin, D.Z., \& Shortell, S.M. (2006). Does large size always slow down learning and implementation? The role of motivation and culture. Working paper, Rutgers Business School -Newark and New Brunswick, Rutgers University, Newark, NJ.

Li, M.H. (2006). The Impact of IT investment, communication, innovation in Participative Budgeting Systems on performance: Hotel Industry in Taiwan as Example, Master's thesis, Graduate School of Business Administration, National Dong Hwa University.

McAdam, R., \& McKeown, M., 1999. Life after ISO 9000: an analysis of the impact of ISO 9000 and total quality management on small businesses in Northern Ireland. Total Quality Management,10(2), 229-241.

Mersha T. (1997). TQM implementation in LDCs: driving and restraining forces, International Journal of Operations \& Production Management, 17(2), 164-183.

Meso, P., \& Smith, R, 2000. A resource-based view of organizational knowledge management system. Journal of knowledge management, 4(13), 224-234.

Miles, R., \& Snow, C. (1978). Organizational Strategy, Structure, and Process. New York: McGraw-Hill.

Miller, J., \& Doyle, B.A. (1987). Measuring effectiveness of computer-based information systems in the financial service sector. MIS Quarterly, 11(1), 107-125.

Motwani, J. (2001). Critical factors and performance measures of TQM. The TQM Magazine, 13(4), 292-300.

Németh, B. (1999). Application of TQM in Hungary and in the US: Analysis. Periodica Polytechnica Social and Management Sciences, $7(1), 3-14$.

Nunnally, J. (1978). Psychometric Theory (2d ed). New York: McGraw-Hill.

Porter, M.E. (1980). Competitive Strategy, New York: The Free Press.

Prajogo, D.I., \& Sohal, A.S. (2006). The relationship between organization strategy, total quality management (TQM), and organization performance- the mediating role of TQM. European Journal of operational Research, 168(1), 35-50.

Prajogo, D.I., \& Sohal, A.S. (2001). TQM and innovation: A literature review and research framework. Technovation, 21(9), 539-558.

Quek, E.E., \& Yusof, S.M. (2003). A Survey of TQM Implementation in Malaysian electrical and electronic industry. Total Quality Management, 14(1), 63-77.

Roberts, C.B. (1996). The Impact of Information Technology on the Management of System Design. Technology in Society, 18(3), 333-355. 
Sakaguchi, T., \& Dibrell, C. (1998). Measurement of the intensity of global information technology usage: Quantitizing the value of a firm's information technology. Industrial Management \& Data Systems, $98(8), 380-394$.

Seetharaman, A., Sreenivasan, J., \& Boon, L.P. (2006). Critical success factors of total quality management. Quality and Quantity, 40(5), 675-695.

Shea, J., \& Gobeli, D. (1995). TQM: the experiences of ten small businesses. Business Horizons, 38(1), 71-77.

Siam, A.Z., Khateeb, K.A., \& Waqqad, S.A. (2012). The role of Information system in implementing Total Quality Management. American Journal of Applied Science, 9(5), 666-672.

Slater, S.F., \& Narver, J.C. (2000). The Positive Effect of a Market Orientation on Business Profitability: A Balanced Replication. Journal of Business Research, 48(1), 69-73.

Sohal, A.S., Moss, S., \& Ng, L. (2001). Comparing IT success in manufacturing and service industries. International Journal of Operations and Production Management, 21(1/2), 30-45.

Song, X.M., Neeley, S.M., \& Zhao, Y. (1996). Managing R\&D-marketing integration in the new product development processes. Industrial Marketing Management, 25(6), 545-553.

Terziovski, M., \& Samson, D. (2000). The effects of company size on the relationship between TQM strategy and organizational performance. The TQM Magazine, 12(2), 144-148.

Tippins, M.J., \& Sohi, R.S. (2003). IT competency and firm performance: Is organizational learning a missing link?. Strategic Management Journal, 24(8), 745-761.

Tiwari, G., \& Chaudhari, P.T. (2012). A study of the effect of information technology on TQM. World Journal of Science and Technology, 2(5), 21-23

Yusof, S.M.,\& Aspinwall, E. (2001). Case studies on the implementation of TQM in UK automotive SMEs. International Journal of Quality \& Reliability Management, 18(7), 722-744.

Yusof, S.M., \& Aspinwall, E. (2000). TQM implementation issues: review and case study. International Journal of Operations \& Production Management, 20(6), 634-655. 